Acta Psychotherap. 1955;3(Suppl. 1):1-6

\title{
Contents, Vol. 3, Supplement 1, 1955
}

List of Papers - Verzeichnis der Vorträge Liste des Communications
G. Adler:
On the Archetypal Content of Transference

J. Bastíaans: Some Problems of the Transference in the Treatment of

Psychosomatic Patients

14

Ch. Baudouín: Transfert et projection en situation analytique

B. J. Becker: A Brief Presentation of Karen Horney's Observations on

Transference and Counter-Transference 25

M. Bergouignan: Observations sur le transfert $\quad 30$

L. Bínswanger: Existential Analysis and Psychotherapy

S. Borellí: Beitrag zum Formenkreis «chronische, unspezifische Urethritis» 38

D. Brinkmann: Paracelsus und das anthropologische Problem der Übertragung $\quad 44$

M. Cave: Psychothérapie des Schizophrénies Juveniles

L. Chertok et

M. Cahen: Facteurs transférentiels en hypnose 56

-R. Le Coultre: Some Special Aspects of the Transference-Phenomenon . . 64

S. Drobnes: The Role of the Psychiatrist in a Tuberculosis Hospital . 67

Ch. Durand et

P. Folch: Le transfert dans la cure pré-analytique

P. Elkisch: Some Thoughts on the Phenomena of Transference and Counter-Transference 81

B, A. Finkelstein: Mißbrauch der Übertragung 84

J. C. Fínney: Interrelationships among Three Psychotic Patients Treated

Simultaneously in Individual and Group Psychotherapy

by the Same Therapist 89

M. Fordham: Note on a Significance of Archetypes for the Transference in Childhood 99

E. C. M. Frijling-

bcnreuder: Some Remarks on Transference and Counter-Transference in Analytical Child Therapy 106

Suppl./4 List of Papers 282

A. Fuchs-Kamp: Analyse der Vergiftungsangst eines pubertierenden Mädcbens in Verbindung mit Übertragungsproblemen .... 109

D. Geddes: A Preliminary Report on the Mass Psychotherapeutic

Treatment of Sex Offenders in California 116

G. H. Graber: Diesseits und jenseits der Übertragung

M. Gruenthal: Testing of the Limits in Active Psychotherapy

H. Häfner: Wertanalyse der therapeutischen Begegnung 
G. Hoffmann: Transference and Therapeutic Goal

139

H. Huebschmann: Von der Übertragung bei der psychischen Behandlung TbcKranker $\quad 145$

W. D. Joel: Transference Reactions of Chronic Regressed Schizo phrenic Patients in Group Psychotherapy 150

L. N. J. Kamp: Transference and Countertransference in Nondirective Psychotherapy 156

W. Kaufman: Transference in the Psychotherapy of Patients with Food Allergies $\quad 162$

TV. Kemper: Die Übertragung im Lichte der Gegenübertragung. . . . 169

W. Kretschmer: Die Übertragung bei Verwendung psycho-therapeutischer Hilfsmethoden 177

D. A. van Krevelen: Probleme der Übertragung in der Psychotherapie des Kindes 181

F. $\quad$ Kruse: Grundsätzliche Unterschiede in der Übertragung männlicher und weiblicher Patienten 188

G. Kühnel: Die Übertragung in der Gruppenanalyse 196

S. Leclaire: Reflexions sur Гétude clinique d'une manifestation de transfert 201

D. M. Lipshutz: Transference in Borderline Cases 210

S. Lorand: The Teaching of Psychotherapeutic Technique to Residents in Psychiatry 218

M. Lowenfeld: The Structure of Transference 224

S. Lowy: Transference in Modified Analytical Therapies 230

I. Macalpíne and

R. A. Hunter: The Importance of the Concept of Transference for Present -

Day Theories of Mental Disease 237

J. L. McCartney: The Application of Electroshock to Expedite Transference 243

W. L. Meíjeríng: The Use of Multiple Transferences in Community Psycho therapy 246

283 Verzeichnis der Vorträge Suppl./5

R. L. Moody: The Relation of Personal and Transpersonal Elements in the Transference 253

W. Niederland: Changing Patterns of Transference in the Treatment of

Obsessive-Compulsive Neurotics 259

G. Pankoiv: Darstellung der Ubertragung in der analytischen Behandlung einer paranoischen Patientin 259

J. H. R. van der

Pas: Ubertragung und Existenz 260

F. Perríer:Sens du transfert dans les psychothérapies de schizophrènes 266

H. Píttrích: Der Einfluß der Ubertragung auf das Schriftbild .... 272

A. B. JГ. Plaut: Research into Transference Phenomena 279

I. Plenge: Zur Frage der Ubertragung auf den jungen Therapeuten . 284

P. Polak: Das Problem der Ubertragung in der Sicht der Anthropologie 293 
A. Poslavsky: Comparison between Psychoanalytic and Non-Directive Situation $\quad 300$

P. J. Reiter: Übertragungsdynamismen bei der Psychotherapie in einer

öffentlichen Klinik 305

E. Rochedíeu: Le transfert et le sentiment religieux 314

J. Ruesch: Transference Reformulated 318

G. Ruffler: Einschätzung der Ubertragung im Hinblick auf die Therapie 327

A. de Ryck: Quelques considerations sur les troubles du comportement chez les épileptiques 337

JR. Schíndler: Übertragungsbildung und Übertragungsführung in der

Psychotherapie mit Schizophrenen 337

W. Schíndler: Transference and Counter-Transference in "Family Pattern"

Group Psychotherapy 345

H.-J. von

Schumann: Die Ubertragung bei Blinden in psychosomatischer Sicht 354

G. Schwöbel: Das Vertrauensverhältnis als Übertragungsproblem in der

Schizophrenie-Therapie $\quad 364$

P. Senft: $\quad$ Transference in Group-Therapy 373

E. Servadío: Le conditionnement transférentiel et contre-transférentiel des événements «psi» au cours de Tanalyse 378

B. Sommer: Übertragungsprobleme in der Behandlung der Pubertätsmagersucht 383

L. Stein: The Terminology of Transference 396

Suppl./6 Liste des Communications 284

M. M. Stern: The Dual Aspect of Transference

F. H. Strauss: Transference Phenomena in a Therapeutic Community . .

H. R. Teirích: Übertragungs- und Rangordnungsprobleme in der Gruppentherapie 409

F. A. Völgyesí: Von den antiken und abergläubisch-magischen Heilmetho-den zur modernen aktiven Seelenheilkunde, mit Rücksicht auf die iatrogenen Übertragungseffekte

A. Wegeler: Biologische Grundlagen der Übertragung 438

E. Weigert: Transference and Countertransference in Relation to Anxiety 443

W. Th, Winkler: Die mehrdimensionale Übertragung

B. Wolstein: Psychoanalysis as the Study of Transference 